\title{
Increasing Understanding of General Knowledge of Plastics with Video-based Learning
}

\author{
Norfatin Afiqah Binti Nashar ${ }^{1}$, Jumintono ${ }^{1, *}$, Rita Rena Pudyastuti ${ }^{2}$, Etty Handayani, ${ }^{3}$, \\ Muhammad Roni Indarto ${ }^{4}$, Jaka Sunardi $^{5}$, Nurcahyani Dewi Retnowati ${ }^{6}$, Sicilia Sawitri ${ }^{7}$ \\ ${ }^{1}$ Faculty of Technical and Vocational Education, Universiti Tun Hussein Onn Malaysia, 86400, Johor, Malaysia \\ ${ }^{2}$ Department of Nursing, Poltekkes Kemenkes Maluku, 97233, Indonesia \\ ${ }^{3}$ Faculty of Agriculture, Universitas Muhammadiyah Yogyakarta, 55183, Indonesia \\ ${ }^{4}$ Department of Management, Sekolah Tinggi Ilmu Manajemen YKPN Yogyakarta, 55581, Indonesia \\ ${ }^{5}$ Faculty of Sport Science, Universitas Negeri Yogyakarta, 55281, Indonesia \\ ${ }^{6}$ Department of Technic of Informatics, Sekolah Tinggi Teknologi Adisutjipto Yogyakarta, 55198, Indonesia \\ ${ }^{7}$ Department of Home Economics, Universitas Negeri Semarang, 50229, Indonesia
}

Received August 3, 2020; Revised September 16, 2020; Accepted October 19, 2020

\section{Cite This Paper in the following Citation Styles}

(a): [1] Norfatin Afiqah Binti Nashar, Jumintono, Rita Rena Pudyastuti, Etty Handayani, Muhammad Roni Indarto, Jaka Sunardi, Nurcahyani Dewi Retnowati, Sicilia Sawitri, "Increasing Understanding of General Knowledge of Plastics with Video-based Learning," Universal Journal of Educational Research, Vol. 8, No. 11B, pp. 5913 - 5917, 2020. DOI: 10.13189/ujer.2020.082225.

(b): Norfatin Afiqah Binti Nashar, Jumintono, Rita Rena Pudyastuti, Etty Handayani, Muhammad Roni Indarto, Jaka Sunardi, Nurcahyani Dewi Retnowati, Sicilia Sawitri (2020). Increasing Understanding of General Knowledge of Plastics with Video-based Learning. Universal Journal of Educational Research, 8(11B), 5913 - 5917. DOI: 10.13189/ujer.2020.082225.

Copyright $\bigcirc 2020$ by authors, all rights reserved. Authors agree that this article remains permanently open access under the terms of the Creative Commons Attribution License 4.0 International License

\begin{abstract}
This study was motivated by video-based learning materials on general knowledge, which is getting more popular. In many cases, video-based education is one of the best ways to learn in today's digital technology. The purpose of this study is to explore the increasing student understanding of learning general knowledge about plastics. This research was conducted using fundamental quantitative analysis in a video tutorial involving 28 respondents from polymer technology students at Mara University Technology (UiTM). The data were collected by giving tests to students before (pre-test) and after (post-test) watching the video. There are five questions students must answer. Data were collected and analysed using the Statistical Package for Science for Windows software Version 21.0 (SPSS V21.0). The frequency and percentage are re-coded to compare the results between pre-test and post-test. A positive response means an increase in the ratio and the percentage of students who get the correct answer on the post-test. This treatment shows a positive response to video-based learning from students. The study results concluded that there was a significant increase compared to before and
\end{abstract}

after the test. Instructional videos make the learning environment more attractive than textbook learning. In this way, learning can provide many benefits for students and teaching staff in increasing their understanding of general knowledge about plastics.

Keywords General Knowledge of Plastics, Thermoplastics, High-density Polyethylene Video-based Learning

\section{Introduction}

The development of digital media technology in the twenty-first century has led to rapid developments, such as moving pictures or videos, as the development and changes in information technology can change community activities, not least in the world of education [1]. The teaching and learning process has experienced extraordinary changes due to the advent of the internet [2]. The internet is the real media in the development and 
transformation of information technology in education. With the development of the internet, learning models such as e-learning, distance learning, web-based learning, and other IT-based education terms emerged. The internet is a global computer network that facilitates and accelerates access to information and knowledge (learning materials). The content in the teaching and learning process can always be updated [3]. It should be that in the application of education available internet access.

In this globalization era, teachers need to be creative and innovative in strengthening the teaching profession so that educators are always up to date with the latest information technology [4]. However, there are still many teachers who use teaching and learning techniques that are not interesting. With the internet network, information search becomes very easy, convenient, and fast because one of the functions of the internet is as a virtual library, providing various types of information for users, including information about teaching and learning techniques. The teacher must know that there are many student learning styles. The term 'learning style' refers to how individuals differ about what teaching or study methods are most useful for them [5]. The use of video in learning is one of the visualization learning styles that significantly influence teaching and learning practices in the classroom, and the use of video in education is recommended. It can be adopted as a way to enhance teacher professional development [6]. Students enjoy their learning more and perform better in an interactive video-based learning environment than students in non-interactive environments. Combining student profiles with content metadata provides opportunities to add value to analytical knowledge obtained from video-based learning [7]. Video-based education is one of the best ways to teach and learn in the era of globalization. There are many advantages to video-based learning, such as increasing interactivity, encouraging thinking, reducing costs, and allowing access through many devices.

Students who ignore the teacher in delivering learning material in class and do not participate during the learning process make them unfocused and unable to understand the topic. With the high development of technology, students become eager to use technological devices to facilitate their learning. Active student participation and high-quality interactions make their learning process meaningful and sustainable [8]. The study [9] shows that the newly designed, enhanced video learning environment is a teaching tool that is superior to standard video learning environments in terms of student learning performance. Besides, video-based learning has developed from passive linear broadcasting into an interactive video experience interesting for students [10].

Plastic is very close to human life. Plastic is one of the materials that is easily found. According to research conducted by [11], plastic that is not following it can cause various health problems because it can cause cancer triggers and tissue damage in the human body (carcinogenic). Plastics consist of repeating units called monomers that bind together to form long chains or polymers [12]. Vinyl plays a vital role in improving the standard life of humans for more than 50 years. Thus, plastic has many social impacts, negative impacts, and positive impacts [13], [14].

Most products used by humans every day are made of plastic, such as toothbrushes, eyeglasses, and more. Students only know that their products are made of plastic. However, unfortunately, students lack knowledge about how to process plastic products and how to treat plastic waste. Students will appreciate each object made of plastic and use it wisely if they understand how to create and manage their waste. The basis of the $4 R$ strategy in the language of waste management is to reduce, reuse, recycle (materials) and recover (energy), with landfills as the least desirable management strategy.

The composition of waste generated from human activities is $60-70 \%$ organic waste, and the rest is $30-40 \%$ inorganic waste, while the second-highest composition of inorganic waste is $14 \%$ is plastic waste. Inorganic waste is complicated to be degraded or even wholly degraded by nature. Inorganic waste that is most often found in the community is plastic waste. Most plastic waste is a type of plastic bag or plastic bag in addition to plastic packaging [15]. In the opinion of [16], plastic has considerable potential as waste, so it is better to utilize this plastic waste to be creating products and services to manage plastic waste properly so that plastic supports human life. Plastic waste management is crucial to reduce diseases that threaten the health of ecosystems and human livelihoods [17].

As polymer technology students, students need to know about the types of plastics that can be recycled to increase awareness about the environment. Today, we can see that many people always throw plastic trash everywhere without thinking about its effects. In 2015, 6300 MT of plastic waste was generated, of which $9 \%$ was recycled, $12 \%$ burned, and $79 \%$ accumulated in landfills or the natural environment [5]. This figure can cause pollution. So, awareness is critical to ensure our environment is not polluted. Plastic recycling is one method to reduce environmental impacts and depletion of resources [18].

With video-based learning, students can understand plastic subjects more efficiently and increase their understanding of general plastic knowledge.

\section{Research Method}

This research was conducted to access general knowledge video-based learning materials about plastics. The research was conducted using quantitative analysis. This study involved five students of the Mara University Technology (UiTM) polymer technology. The research 
instrument consists of objectives consisting of 2 multiple-choice questions, namely A (Yes) and B (No). Students must answer all test questions based on their knowledge. The questions were distributed on paper to students twice, namely pre and post-test. The pre-test was carried out before the students watched the video, while the post-test was carried out after the students watched the video. Respondents watched a 15-minute video uploaded on YouTube before answering the post-test. Data were analysed using Statistical Package for Science (SPSS) version 21 . Data were analysed statistically descriptively to find frequencies and percentages.

\section{Result and Discuss}

Based on the introductory aquaponic video, five questions have been developed. The results consist of tests before and after watching introductory aquaponic animation videos. Results are recorded in frequency and percentages. The purpose of this objective question test is to determine the level of student knowledge. This objective question test aims to assess the level of student knowledge. The results of the pre-test and post-test research can be seen in table 1 .

The first question is the definition of thermoplastics - more at the level of student cognition in memory. From table 1, the percentage shows that students who failed to answer correctly for the pre-test for question one was $75.0 \%$. The results of the answers above indicate that four respondents could not answer this question correctly. For the post-test, the percentage of students who cannot answer correctly is $14.3 \%$, which means that only one student failed to answer it. From table 1, it can be seen that there is an increase in students' understanding before and after watching the video. Five students can answer correctly in the post-test, and one student cannot answer correctly due to misunderstanding or being unfocused while watching the video. The findings [19] show that the majority of students who use video are useful for accepting some types of enhanced learning, including increased understanding of topics and greater ease of learning.

Question 2 is about thermoplastic characteristics. Students must choose incorrect answers about thermoplastic components because, in the subject, it states the word 'except.' From table 1, only $17.9 \%$ of students who were one student answered correctly during the post-test, of which only one student got the correct answer. After watching the video, it shows the percentage of students' responses successfully increased by around $50 \%$, i.e., four students got the right answers. In contrast, the other two students got the wrong answer because they did not carefully read the question.

Table 1. Respondents' answers to each question

\begin{tabular}{|c|c|c|c|c|c|c|}
\hline \multirow{2}{*}{ No. } & \multirow{2}{*}{ Question } & \multirow{2}{*}{$\begin{array}{l}\text { Respondents } \\
\text { Answer }\end{array}$} & \multicolumn{2}{|c|}{ Pre-Test } & \multicolumn{2}{|c|}{ Post-Test } \\
\hline & & & Frequency & Percentage & Frequency & Percentage \\
\hline \multirow{3}{*}{1} & \multirow{3}{*}{ What are thermoplastics? } & Yes & 7 & 25.0 & 24 & 85.7 \\
\hline & & No. & 21 & 75.0 & 4 & 14.3 \\
\hline & & Total & 28 & 100.0 & 28 & 100.0 \\
\hline \multirow{3}{*}{2} & \multirow{3}{*}{ The characteristics of Thermoplastics } & Yes & 5 & 17.9 & 19 & 67.9 \\
\hline & & No. & 23 & 82.1 & 9 & 32.1 \\
\hline & & Total & 28 & 100.0 & 28 & 100.0 \\
\hline \multirow{3}{*}{3} & \multirow{3}{*}{ The type of thermoset resin } & Yes & 3 & 10.7 & 26 & 92.8 \\
\hline & & No. & 25 & 89.3 & 2 & 33.3 \\
\hline & & Total & 6 & 100.0 & 6 & 100.0 \\
\hline \multirow{3}{*}{4} & \multirow{3}{*}{$\begin{array}{l}\text { Symbol of High-density Polyethylene } \\
\text { (HDPE) }\end{array}$} & Yes & 14 & 50.0 & 28 & 100.0 \\
\hline & & No. & 14 & 50.0 & 0 & 0 \\
\hline & & Total & 28 & 100.0 & 28 & 100.0 \\
\hline \multirow{3}{*}{5} & \multirow{3}{*}{ The injection molding process } & Yes & 0 & 0 & 23 & 82.1 \\
\hline & & No. & 28 & 100.0 & 5 & 17.9 \\
\hline & & Total & 28 & 100.0 & 6 & 100.0 \\
\hline
\end{tabular}


In question 3, students need to choose the type of thermoset resin. Students need to understand the character of thermoset resin. Students must compare each type of plastic before answering this question. For the pre-test, the percentage of students' wrong answers was $89.3 \%$, while the post-test was $7.2 \%$. The results above show a decrease of about $82.1 \%$ of students answered incorrectly. During the pre-test, only two students answered correctly, while in the post-test, the number of students who answered correctly was four students. This result shows students' understanding of the characteristics of increased thermosets after watching the video.

In question 4, students need to choose the HDPE symbol. This symbol is more about remembering. In the initial exam, only half of the students who got $50 \%$ got the correct answer. After watching the video, all students get the right answer. Based on the results, this shows a significant percentage increase. This result indicates that students can remember symbols when displayed in colourful background. Besides, it also improves students' understanding of high-density polyethylene. Therefore, video-based learning is safe and can attract students' attention to watch. This finding is in line with the opinion [20], who believe that students who learn to use technology have a higher score than those who do not use it. The learning through video is more precise and more detailed. However, according to [21], watching videos with short duration will be more exciting than videos for an extended period.

In question 5 , it is about the order of the injection molding process. To sequence the process, students must understand the process so students will choose the correct answer. Table 5 shows that all students gave incorrect answers for the pre-test because they messed up the order of the process. However, after watching the video, it showed that the percentage of students getting the wrong answers decreased by around $82.1 \%$. Students can see the accurate processing of injection moulds in the video compared to just seeing in the picture from the video. In the video, you can see how to process products from raw materials into products using injection moulding. Thus, it can be concluded that video-based learning impacts students in understanding the injection moulding process. Job enrichment encourages more skilled and skilled workers in their fields and can complete more massive tasks on their terms, including in education [22].

\section{Conclusions}

The findings of this study indicate that video-based learning increases students' general understanding of plastic topics. The post-test results after watching the video showed an increase in the percentage of students who got the right answer. Video-based learning also makes the learning environment more interesting besides textbooks.
Thus, video-based education provides many advantages for students in improving understanding of general plastic knowledge.

\section{Acknowledgments}

The author would like to thank Research Fund E15501, Research Management Centre, UTHM for its support and funding.

\section{REFERENCES}

[1] D. G. H. Divayana, P. W. A. Suyasa, and N. Sugihartini, 'Pengembangan Media Pembelajaran Berbasis Web Untuk Matakuliah Kurikulum dan Pengajaran di Jurusan Pendidikan Teknik Informatika Universitas Pendidikan Ganesha', J. Nas. Pendidik. Tek. Inform., vol. 5, no. 3, p. 149, Dec. 2016.

[2] Z. Abd Rashid, 'Review of Web-Based Learning in TVET: History, Advantages, and Disadvantages,' Int. J. Vocat. Educ. Train. Res., vol. 2, no. 2, p. 7, 2016.

[3] A. Muhson, 'Pengembangan Media Pembelajaran Berbasis Teknologi Informasi', J. Pendidik. Akunt. Indones., vol. 8, no. 2, Dec. 2010.

[4] M. N. Giannakos, K. Chorianopoulos, M. Ronchetti, P. Szegedi, and S. D. Teasley, 'Video-Based Learning and Open Online Courses,' Int. J. Emerg. Technol. Learn., vol. 9, no. 1, pp. 4-7, 2014.

[5] R. Geyer, J. R. Jambeck, and K. L. Law, 'Production, Use, and Fate of All Plastics Ever Made,' Sci. Adv., vol. 3, no. 7, Jul. 2017.

[6] O. Poquet, L. Lim, N. Mirriahi, and S. Dawson, 'Video and Learning: A Systematic Review (2007-2017)', in ACM International Conference Proceeding Series, 2018, pp. 151160.

[7] M. N. Giannakos and P. Vlamos, 'Using Webcasts in Education: Evaluation of its Effectiveness,' Br. J. Educ. Technol., vol. 44, no. 3, pp. 432-441, May 2013.

[8] M. H. Liu, 'Blending a Class Video Blog to Optimize Student Learning Outcomes in Higher Education', Internet High. Educ., vol. 30, pp. 44-53, Jul. 2016.

[9] E. Delen, J. Liew, and V. Willson, 'Effects of Interactivity and Instructional Scaffolding on Learning: Self-regulation in Online Video-based Environments', Comput. Educ., vol. 78, pp. 312-320, 2014.

[10] M. Merkt, S. Weigand, A. Heier, and S. Schwan, 'Learning with Videos vs. Learning With print: The Role of Interactive Features', Learn. Instr., vol. 21, no. 6, pp. 687-704, Dec. 2011.

[11] R. Proshad, T. Kormoker, M. S. Islam, M. A. Haque, M. M. Rahman, and M. M. R. Mithu, 'Toxic Effects of Plastic on Human Health and Environment: A Consequences of Health Risk Assessment in Bangladesh', Int. J. Heal., vol. 6, no. 1, p. 
1, Dec. 2017.

[12] C. M. Rochman et al., 'Policy: Classify Plastic Waste as Hazardous', Nature, vol. 494, no. 7436, pp. 169-170, Feb. 2013.

[13] P. Kumar, 'Role of Plastics on Human Health', Indian J. Pediatr., vol. 85, no. 5, pp. 384-389, May 2018.

[14] R. C. Thompson, C. J. Moore, F. S. V. Saal, and S. H. Swan, 'Plastics, the Environment and Human Health: Current Consensus and Future Trends', Philos. Trans. R. Soc. B Biol. Sci., vol. 364, no. 1526, pp. 2153-2166, Jul. 2009.

[15] P. Purwaningrum, 'Upaya Mengurangi Timbulan Sampah Plastik di Lingkungan', Indones. J. Urban Environ. Technol., vol. 8, no. 2, p. 141, Dec. 2016.

[16] H. P. Putra and Y. Yuriandala, 'Studi Pemanfaatan Sampah Plastik Menjadi Produk dan Jasa Kreatif', J. Sains \&Teknologi Lingkung., vol. 2, no. 1, pp. 21-31, Mar. 2010.

[17] J. B. Lamb et al., 'Plastic Waste Associated With Disease on Coral Reefs', Science (80-. )., vol. 359, no. 6374, pp. 460462, Jan. 2018.
[18] J. N. Hahladakis, C. A. Velis, R. Weber, E. Iacovidou, and P. Purnell, 'An Overview of Chemical Additives Present in Plastics: Migration, Release, Fate and Environmental Impact During their use, Disposal and Recycling', J. Hazard. Mater., vol. 344, pp. 179-199, Feb. 2018.

[19] H. David Brecht, 'Learning from Online Video Lectures', $J$. Inf. Technol. Educ. Innov. Pract., vol. 11, pp. 227-250, 2012.

[20] M. Ahmad, N. H. Sleiman, M. Thomas, N. Kashani, and M. M. Ditmyer, 'Use of High-Definition Audiovisual Technology in a Gross Anatomy Laboratory: Effect on Dental Students' Learning Outcomes and Satisfaction', J. Dent. Educ., vol. 80, no. 2, pp. 128-132, Feb. 2016.

[21] P. J. Guo, J. Kim, and R. Rubin, 'How Video Production Affects Student Engagement: An Empirical Study of MOOC Videos', in L@S 2014 - Proceedings of the 1st ACM Conference on Learning at Scale, 2014, pp. 41-50.

[22] M. Z. Mustafa, Y. Buntat, M. A. Omar, A. R. A. Razzaq, and R. Ahad, 'Organizational Commitment Survey: A Confirmatory Factorial Analysis Based on Vocational Colleges Teachers Sample', Int. J. Eng. Adv. Technol., vol. 8, no. 5C, pp. 279-288, May 2019. 